\title{
Tres Rios constructed wetlands: maximizing beneficial reuse while balancing demands of diverse stakeholder needs
}

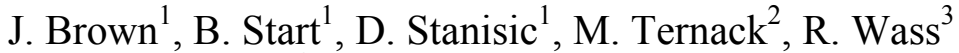 \\ \& J. Coughenour ${ }^{4}$ \\ ${ }^{1}$ Jacobs Engineering Group, USA \\ ${ }^{2}$ US Corps of Engineers, USA \\ ${ }^{3}$ Wass Gerke \& Associates, USA \\ ${ }^{4}$ City of Phoenix, USA
}

\begin{abstract}
The effluent flows from the $91^{\text {st }}$ Avenue Wastewater Treatment Plant (WWTP) are a coveted and valuable water resource in the Phoenix area. The current effluent flows of 130-150 mgd are nearly fully allocated, providing cooling water to the Arizona Nuclear Power Project (ANPP) and supplying agricultural users in the Buckeye Irrigation District (BID). The Tres Rios flow regulating and overbank wetlands provide a second tier of reuse. Whilst conveying the effluent to downstream customers, the wetlands provide approximately 300 acres of rare and valuable wetland habitat. In addition, the wetlands will remove total residual chlorine naturally, and achieve advanced ammonia and total nitrogen removal. This paper provides a summary of the wetland design and discusses the challenges of operating a large scale constructed wetland. These include optimizing process control and vegetation maintenance to maintain habitat value and meet treatment objectives, balancing water requirements of the wetlands with downstream customers, controlling mosquitoes and other vectors, overcoming regulatory hurdles, and assessing the cost/benefits of the wetlands over mechanical treatment processes.
\end{abstract}

Keywords: effluent reuse, constructed wetlands, riparian habitat, tamarisk infestation, mosquito control, dechlorination, constructed wetland start-up. 


\section{Introduction}

The Tres Rios Wetlands are located near the confluence of three rivers, the Salt, Gila and Agua Fria Rivers. Over 100 years ago, prior to the construction of modern dams and diversion canals, the rivers' flood plains were productive riparian areas consisting of cottonwood and willow forests and expansive mesquite bosques. The area provided habitat for diverse fish and wildlife. Starting in 1903, when the Roosevelt Dam was completed, a system of canals and dams was constructed, which essentially diverts $100 \%$ of the rivers' nonflood flow for agricultural or urban use. The US Dept. of Interior estimates that $90 \%$ of the riparian forests were eliminated, leaving small sections fed by wastewater effluent and occasional storm drain run-off [1].

The Tres Rios wetlands project was conceived in 1993 when the five Phoenix-area cities that own capacity at the 91st Avenue WWTP (the Subregional Operating Group or SROG cities of Glendale, Mesa, Phoenix, Scottsdale and Tempe) collaborated with the US Bureau of Reclamation in a study to integrate effluent conveyance and reuse and storm water management near the $91^{\text {st }}$ Avenue WWTP. The study determined that constructed wetlands would achieve these goals as well as improve fish and wildlife habitat in the area and provide recreational and educational opportunities for the community.

In 1995 demonstration wetlands were constructed, consisting of 4 cells over a total of 10 acres. These operated continuously for 15 years providing valuable data and operational experience that guided the design of the large scale wetlands. In 1997, the US Army Corps of Engineers (USACE), Los Angeles District, initiated a feasibility study for the large scale wetlands, which recommended construction of full scale wetlands [1]. The City of Phoenix (City) and the USACE partnered to construct the full scale wetlands which were completed in the fall of 2010. The wetlands are still in the start-up phase, but valuable data is being collected, and the new habitat is being populated.

\subsection{Summary of stakeholders}

The principal objective of the Tres Rios Wetlands is to provide additional riparian habitat to replace habitat lost to the last century of agricultural and urban development. The project sponsors, the City of Phoenix and the USACE, are two of a diverse group of stake holders. Other stake holders include the downstream effluent users, the Arizona Nuclear Power Project (ANPP), and the Buckeye Irrigation District (BID), federal and state regulators such as the EPA and Arizona Department of Environmental Quality (ADEQ), and the other SROG Cities.

\section{Design objectives}

The USACE and the City of Phoenix, as a local sponsor, funded and executed this project with the following objectives:

- Environmental restoration (additional fish and wildlife habitat)

- Water quality improvements (effluent polishing) 
- Flood control and storm water management

- Salt River north bank restoration

- Water conservation and reuse

- Effluent conveyance

- Passive recreational and educational opportunities

The wetland's primary objective is to provide a diverse wetland habitat. The wetland's water quality improvement capacity is a secondary design objective that was critical for gaining support from EPA/ADEQ and the SROG Cities. Flood control and storm water management benefits were critical in obtaining support from the USACE. The wetland design balances these design objectives, addressing concerns and providing benefits to the diverse group of stake holders. This section will discuss only the environmental restoration and water quality improvement objectives.

\subsection{Process overview}

The wetlands, shown in the west facing aerial photograph below, consist of various wetland basins. The two deep water basins at the lower right (DWA and DWB) receive water from a new dedicated pump station located at the $91^{\text {st }}$ Avenue WWTP. These basins are hydraulically connected and stabilize the flow to the downstream basins. Directly downstream of the deep water basins are three flow regulating wetland cells operating in parallel (FRW1, FRW2, and FRW3). The bulk of the water quality improvements occur in these cells, and

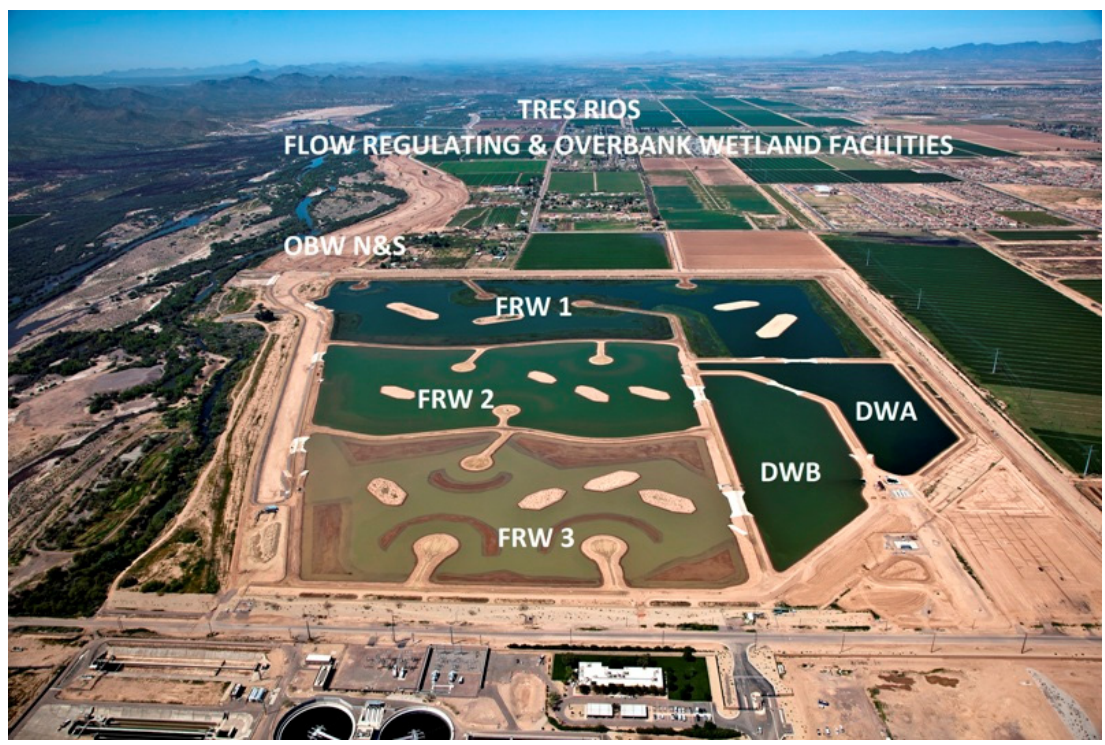

Figure 1: $\quad$ Tres Rios Wetlands. 
the combined effluent is monitored for water quality compliance. This water can either be discharged to the Salt River, or directed to the Overbank Wetlands (OBW), which consist of two parallel basins on the north bank of the Salt River. The OBW north basin consists of emergent marsh and deep water zones, similar to the FRW, and the south overbank wetland includes both mesquite bosque and cottonwood/willow habitat that is periodically flood irrigated to maintain the vegetation. The OBW basins will be open to the public.

The wetland's size, and thus its capacity to treat effluent, was dictated by available land and funding, rather than water quality process needs. In addition, the design flow range ( $40 \mathrm{mgd}$ up to $91^{\text {st }}$ Avenue's entire plant flow) results in wetland loading rates much higher than typically seen for constructed wetlands. The wetlands are currently receiving $25 \mathrm{mgd}$ of secondary effluent from $91^{\text {st }}$ Avenue. Some of this is being used to maintain water levels in FRW2 and FRW3 while biology is being developed, and the remainder is treated in FRW1 and discharged. $25 \mathrm{mgd}$ is below design and results in a loading of approximately $0.4 \mathrm{ft} /$ day (not including the OBW). This loading has proven adequate for maintaining the wetland's habitat and meeting treatment goals.

Table 1: $\quad$ Wetland Basin sizes.

\begin{tabular}{|c|c|c|c|}
\hline & Total area & \multicolumn{2}{|c|}{ Total Volume } \\
\hline Cell & (acres) & million gal & acre feet \\
\hline DWA & 12 & 30 & 100 \\
\hline DWB & 16 & 40 & 120 \\
\hline FRW1 & 100 & 100 & 300 \\
\hline FRW2 & 43 & 50 & 150 \\
\hline FRW3 & 34 & 40 & 120 \\
\hline Effluent Channel & 12 & 1 & 4 \\
\hline OBW N & 21 & 15 & 45 \\
\hline Mesquite Bosque & 52 & - & - \\
\hline Cottonwood/willow forest & 13 & - & - \\
\hline Total & 303 & 276 & 839 \\
\hline
\end{tabular}

The dedicated pump station for the wetlands has the capacity to deliver $190 \mathrm{mgd}$ ( $80 \mathrm{mgd}$ firm capacity), and is being expanded to $380 \mathrm{mgd}$ ( $270 \mathrm{mgd}$ firm capacity).

\subsection{Environmental restoration}

The Tres Rios Wetlands provide approximately 300 acres of new riparian habitat in the Tres Rios study area, which includes approximately 8 miles of the Gila River from $83^{\text {rd }}$ Ave to the Agua Fria River. Existing and new habitat area is tabulated below. 
Table 2: Riparian habitat.

\begin{tabular}{|c|c|c|}
\hline Habitat type & $\begin{array}{c}\text { Existing Area } \\
\text { (acres) [1] }\end{array}$ & $\begin{array}{c}\text { Tres Rios Area } \\
\text { (acres) [2] }\end{array}$ \\
\hline Cotton wood/Willow & 450 & 22 \\
\hline Salt Cedar & 1300 & 0 \\
\hline Mesquite Bosque & 160 & 52 \\
\hline Open water & 470 & 126 \\
\hline marsh & 16 & 104 \\
\hline total habitat & 2396 & 304 \\
\hline
\end{tabular}

This list does not include cobble, desert wash, agricultural, residential, and gravel mine lands within the study area. It is important to note that the invasive Salt Cedar (Tamarisk) has marginalized $68 \%$ of the existing terrestrial forest habitat. The Tres Rios wetlands, in contrast to the salt cedar monoculture, are diverse by design. The various habitat areas are summarized below.

\subsubsection{Emergent marsh}

The Tres Rios Wetlands provide 104 acres of marsh. This is divided into shallow hummock (0-0.5 feet) and deep marsh (0.5-1.0 feet) to provide a range of water depths and plants adapted to those depths. Plants include various bulrush and cattail species, broadleaf arrowhead and water speedwell.

Bacteria, responsible for removing carbonaceous and nitrogenous waste, form films on the stalks, roots, leaves, and bottom soils exposed to the water column. The bacteria arguably provide the greatest water quality benefits within the wetlands. The shallow marsh also has higher potential for mosquito production. To aid with mosquito control, the shallow habitat is located close to maintenance roadways for effective application of mosquito larvacide when necessary, and easy access for vegetation removal (mechanical or controlled burning).

\subsubsection{Deep water}

The deep water habitat provides open water that attracts migratory birds and provides habitat for fish. The open water allows for wave driven oxygen transfer, and the depth provides necessary hydraulic capacity for high flow events. The 126 acres of deep water will be partially planted with floating and submerged aquatic plants. These plants provide available carbon and a physical substrate for beneficial bacterial bio films.

\subsubsection{Terrestrial}

The terrestrial habitat is not directly in contact with the water column, and is not essential for the wetlands' water treatment processes. It is, however, an important part of the wetland's habitat value. Terrestrial habitat includes large riparian trees such as cotton woods and willows on islands within the basins. Such large canopy forest provides nesting area for large birds, migratory song birds, and is home to various small mammals and reptiles. Mesquite bosque, consisting of desert trees and shrubs upland from wetland zones, provides habitat for similar populations. 


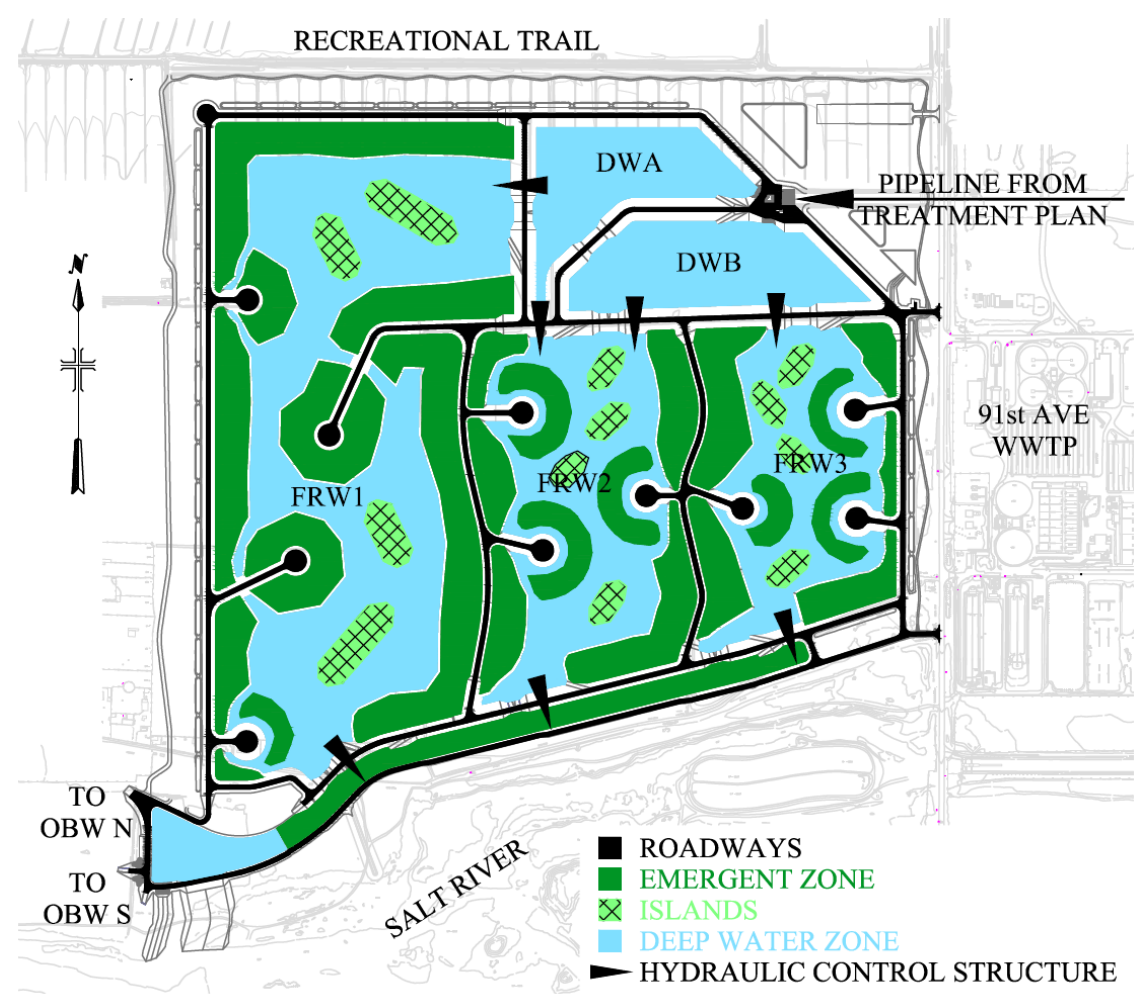

Figure 2: $\quad$ Flow regulating wetlands habitat.

Figure 2 illustrates how the various habitats are distributed through the flow regulating wetlands.

Note that the open water and marsh habitat are in parallel. This means that much of the water will bypass the marshes, especially during high flow rates. For wetlands tasked with water quality improvement only, this would allow unacceptable bypassing of the most efficient treatment zones. The Tres Rios Wetlands are not thus burdened, and a parallel configuration provides the most hydraulic flexibility. It also allows the marsh areas to be dewatered while still allowing flow through the wetlands.

\subsection{Water quality improvements}

Though a secondary objective, the wetlands capacity for water quality improvements was critical for securing funding from the City of Phoenix and support from the other SROG Cities. In Arizona, water quality regulators (ADEQ) have imposed the standard of Best Available Demonstrated Control Technology (BADCT) for new WWTPs, and for WWTPs that expand their capacity. BADCT performance requirements include a total nitrogen 
requirement, and strict disinfection requirement (4 of 7 daily samples must be non detect for E. Coli). Discharge monitoring results demonstrate that $91^{\text {st }}$ Avenue routinely meets BADCT for all parameters except for disinfection. Secondary filtration and some form of advanced disinfection would be necessary to achieve BADCT for disinfection. However, ADEQ worked with the City of Phoenix, and allows the plant to meet BADCT by achieving advanced nitrogen removal in the wetlands instead of meeting the disinfection standard. Because the plant has integrated the wetlands into the process, tertiary filtration and advanced disinfection were not required to expand the facility, and SROG saved hundreds of millions of dollars in capital and operating costs. Thus the wetland's impact on water quality was a major project driver.

With the wetlands in place, the $91^{\text {st }}$ Ave WWTP has maintained its current permit limits, some of which are summarized in the table below. The compliance point is at the wetland effluent for all parameters except E. Coli.

Table 3: $\quad$ Tres Rios permit limits [3].

\begin{tabular}{|c|c|c|}
\hline Parameter & Tres Rios Influent & $\begin{array}{l}\text { Tres Rios Effluent } \\
\text { (Monthly Average) }\end{array}$ \\
\hline $\begin{array}{c}\text { Total Residual Chlorine } \\
\text { Ammonia (as N) }\end{array}$ & $\begin{array}{l}\text { Monitor Only } \\
\text { Monitor Only }\end{array}$ & $\begin{array}{c}11.0 \mathrm{ug} / \mathrm{L} \\
1.99-2.92 \mathrm{mg} / \mathrm{L}\end{array}$ \\
\hline $\begin{array}{l}\text { Total Nitrogen (as } \mathrm{N})^{2} \\
\text { Whole Effluent Toxicity }\end{array}$ & $\begin{array}{l}\text { Monitor Only } \\
\text { Monitor Only }\end{array}$ & $\begin{array}{c}10 \mathrm{mg} / \mathrm{L} \text { (5-Month Rolling Avg } \\
\text { Limit) } \\
1.0 \mathrm{Tuc}\end{array}$ \\
\hline CBOD5 & Monitor Only & 25 mg/L (Monthly Average) \\
\hline TSS & Monitor Only & 30 mg/L (Monthly Average) \\
\hline E. Coli & $\begin{array}{l}126 \mathrm{MPN} / 100 \mathrm{~mL} \\
\text { (Geo Mean) } \\
575 \mathrm{MPN} / 100 \mathrm{~mL} \\
\text { (Daily Max) }\end{array}$ & Monitor Only \\
\hline
\end{tabular}

${ }^{1}$ Ammonia limits vary with season; the value shows the range between summer and winter.

${ }^{2}$ APP (Aquifer Protection Permit) limit, all others NPDES (National Pollutant Discharge Elimination System) Permit limits.

Presently, secondary effluent water quality is excellent, and all Table 3: water quality discharge limits would be met prior to the wetlands, except for total residual chlorine. The wetlands have successfully "dechlorinated" flows, preventing the need for chemical dechlorination.

\section{Operations}

The new wetlands have been integrated into the $91^{\text {st }}$ Avenue WWTP Operations. A general operational schematic is shown in the figure below. Flow values represent January 2011 conditions. 


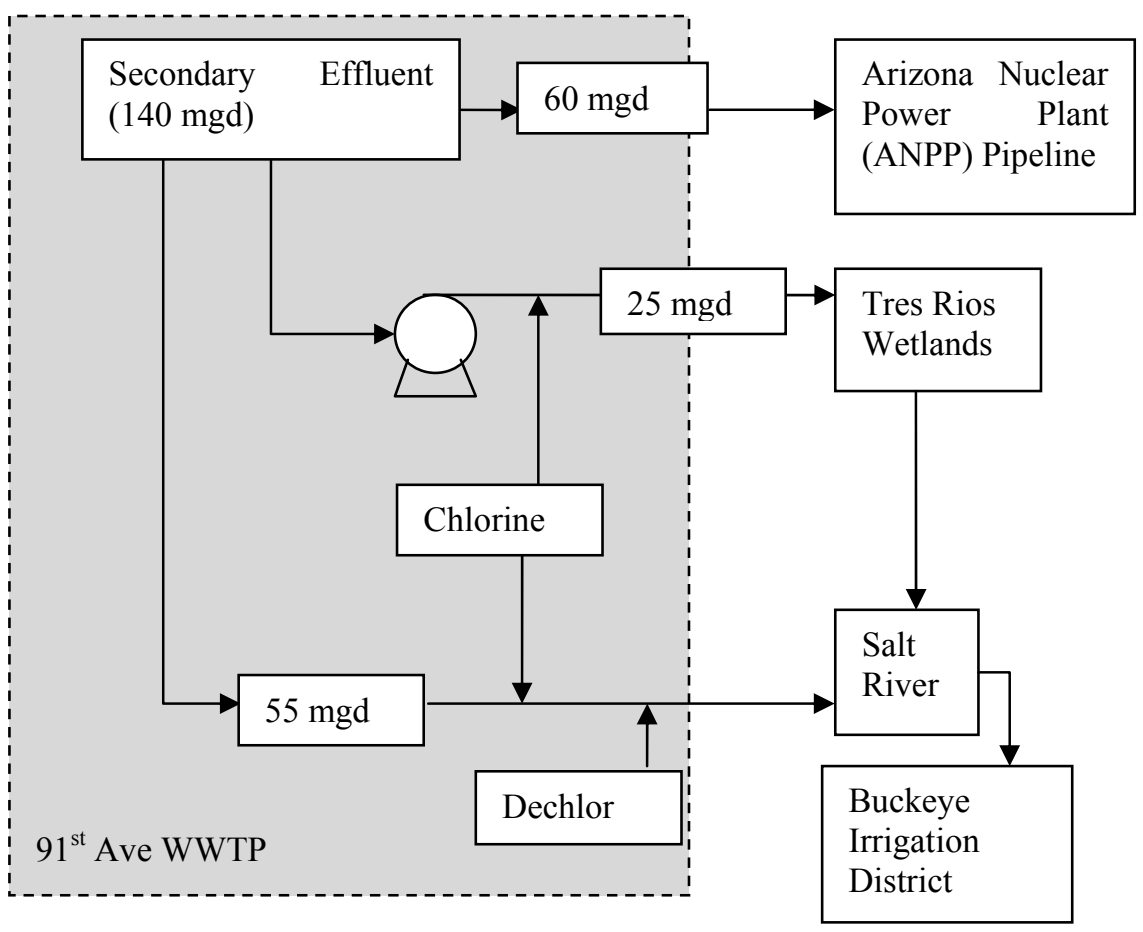

Figure 3: $\quad$ 91st Ave WWTP effluent reuse schematic.

Part of the secondary effluent is delivered by gravity directly to the ANPP pipeline prior to disinfection. Another part is chlorinated and pumped to the Tres Rios Wetlands. The remainder is chlorinated and dechlorinated and discharged to the Salt River. The Salt River conveys effluent to the Buckeye irrigation district (BID).

Delivering effluent to the wetlands includes an additional cost of pumping ( $25 \mathrm{ft}$ of head) but eliminates the costs of chemical dechlorination. These costs are roughly the same at $\$ 10-\$ 15$ per million gallons.

\subsection{Process control}

Automated controls will be used to manipulate flows into and through the wetlands, and to temporarily take basins out of service. All flow to the wetlands is pumped, but flow into the pump station reflects the diurnal flow into the WWTP. These flows leave the inlet structure (top right of figure 2) and flow into the deep water basins DW-A and DW-B. Flow from the deep water basins passes through hydraulic control structures. Motor operated sluice gates within these structures will be raised and lowered to modulate the flow, which is measured by Acoustic Doppler Flow Meters (ADFM) mounted within the control structures. The water level in the FRWs will be controlled by adjustable 
weir gates, which are also motor operated and located in hydraulic control structures at the south end of each basin. From the FRW basins effluent is collected in the shallow effluent channel and directed to the OBW or the Salt River. A central computer control system at the $91^{\text {st }}$ Avenue WWTP will be used to automate the flow and level control.

\subsection{Vector control}

Mosquito control emerged as the primary operational challenge at the demonstration wetlands. Experience with the demonstration wetlands revealed that a combination of larvacide application, fish that prey on mosquito larvae, and vegetation removal by controlled burning were the most effective methods of mosquito control [4].

Larvacide used includes Bacillus thuringensis variety Israelensis (BTI) and Bacillus Sphaericus (BS) [5]. These are used because they specifically target larvae and not other organisms including humans. The granular larvacide is broadcast from the maintenance roadways onto the emergent marsh zones. Mosquito fish Gambusia affinis are also stocked in the wetlands. These fish are known to prey on mosquito larvae. The marsh vegetation must allow the mosquito fish to swim freely. If the vegetation becomes too dense, then the fish cannot reach the mosquito larvae. The wetland vegetation will be removed by burning every three years to maintain appropriate plant density.

\subsection{Invasive species}

Just as the river is marginalized by salt cedar, the wetlands are also susceptible to infestation. Regular preventive maintenance is required to prevent salt cedars from overcrowding the shores and islands within the wetlands. As seen at the demonstration facilities, long term salt cedar control has been achieved by allowing the native riparian vegetation to thrive and thus out compete the exotic species [3]. This outcome is expected in the full-scale facilities.

\subsection{Water losses}

During summer months, the effluent is close to being fully allocated so any "losses" through the wetlands may have to be compensated with supplemental water. Summer peak usage for the ANPP can be up to $86 \mathrm{mgd}$. ANPP peak summer demand-unfortunately coincides with $91^{\text {st }}$ Avenue's period of lowest effluent flow, about $135 \mathrm{mgd}$. This leaves about $50 \mathrm{mgd}$ to support the wetlands, the Salt River riparian area and the BID.

The "losses" due to the wetlands reduce downstream flow. A true loss, evapo-transpiration, is estimated between 0.35 and 0.4 inches/day during June [2], the peak month. This results in a loss of about $3 \mathrm{mgd}$. Losses due to percolation, though not truly lost, are also considered. Percolation "losses", of $0.1 \mathrm{ft} /$ day (observed at the demonstration wetlands [2]), result in approximately $8 \mathrm{mgd}$. Percolation losses are heavier at start-up but will reduce as the wetlands cells mature and the bottoms seal. 
The subsurface flow of water, and the gaining nature of the Salt River channel compensate for infiltration losses, but not the losses due to evapotranspiration. The wetlands have two additional water sources available to compensate. First, there are dewatering wells on the WWTP used to keep the water table safely below the treatment plant infrastructure. These wells, with a total capacity of $30 \mathrm{mgd}$ (currently $6 \mathrm{mgd}$ can be directed to the wetlands [3]), can temporarily augment effluent flow. The second water source is surface water delivered from the local raw water supplier, Salt River Project (SRP). This water can be delivered to the OBWs only, and could supply enough water to meet the OBW water demand.

\subsection{Start-up challenges}

The wetlands experienced a unique path to start up. Two critical path items, the pumping station to deliver flows to the wetlands, and the discharge permit allowing flow from the wetlands to the Salt River, were delayed and altered the start-up. To avoid delays, the bulrush in FRW 1 was established with a temporary mechanical irrigation system. The contractor elected to wait for the pump station start-up before planting the other basins. When the pumping station was brought online, and effluent was available to the wetlands, flows could not leave the wetlands because the discharge permit was not yet completed. During this time, the wetlands operated essentially as recharge basins. Finally, the contractor maintained control of the flow within the wetlands after the discharge permit was issued because final completion was not yet in place. This prevented the City of Phoenix from taking over operations and controlling flows after they entered the wetlands. Operations were turned over completely to the City in January 2011.

Even without the setbacks listed above, the transition from dry sterile basins into lush vibrant wetlands is difficult. Unlike mechanical treatment plants, which can receive and treat water upon substantial completion of the civil and mechanical works, the wetlands must wait for vegetation to mature. Even after the vegetation is mature, the microbiology and sediments must mature. This requires several complete life cycles of the marsh plants to deposit organic matter onto the sediments, and for various populations of bacteria to populate the aerobic, anoxic, and anaerobic zones within the sediments. Only after the vegetation, sediments, and bacterial populations have matured, will the wetland start up be complete.

As expected, some early sample results from the immature wetlands were out of range. Most notable was the high $\mathrm{pH}$ levels attributed to excessive algal growth. $\mathrm{pH}$ levels exceeded the discharge limit of 9.0 from the August 2, 2010 start-up through mid-September. At the time of this writing, $\mathrm{pH}$ is within range, but higher than target. Staff has applied 150 bales of hay to FRW1 to try to accelerate the development of a layer of decomposing organic matter to accelerate the growth of bacterial populations and organic acid formation on the basin floors.

In spite of these challenges, the wetlands have been providing benefits to wildlife and effluent water quality. Limited data is available to demonstrate the 
water quality benefits already being seen. The following table has the average values observed in the three month period from October 1, 2010 through January $1,2011$.

Table 4: $\quad$ Tres Rios operational data [3].

\begin{tabular}{|c|c|c|}
\hline Parameter & Tres Rios Influent & Tres Rios Effluent \\
\hline $\mathrm{pH}$ & 7.3 & 8.4 \\
\hline $\begin{array}{c}\text { Total Residual Chlorine } \\
(\mathrm{mg} / \mathrm{L})\end{array}$ & 1.8 & 0.0 \\
\hline Ammonia $(\mathrm{mg} / \mathrm{L}$ as N) & 1.1 & 0.4 \\
\hline Total Nitrogen $(\mathrm{mg} / \mathrm{L}$ as $\mathrm{N})$ & 6.4 & 5.2 \\
\hline COD $(\mathrm{mg} / \mathrm{L})$ & 22 & 30 \\
\hline TSS $(\mathrm{mg} / \mathrm{L})$ & 8 & 20 \\
\hline E. Coli $(\mathrm{MPN} / 100 \mathrm{~mL})$ & 0 & 370 \\
\hline
\end{tabular}

The data shows successful removal of total residual chlorine, ammonia, and a slight improvement in total nitrogen. Total nitrogen removal will pick up when the wetlands move from highly aerobic to facultative. COD and TSS results in the Tres Rios effluent are higher than those at the traditional outfall at $91^{\text {st }}$ Avenue, but still safely meet permit requirements. E. coli is the only Tres Rios effluent parameter that exceeds Table 3 limits, but compliance for coliforms is demonstrated by sampling into the wetlands, and it was widely understood that coliform counts would rise in the wetlands, a natural system without chlorine.

\subsection{Regulatory sampling requirements}

The EPA believes that there is much to learn from the wetlands during the first few years of operation. To capitalize on this opportunity, the EPA has greatly expanded effluent monitoring. Historically, the WWTP collected compliance samples at the traditional outfall at $91^{\text {st }}$ Avenue. This sampling and analysis continues, but parallel monitoring is now required at the influent to the Flow Regulating Wetlands, at the discharge from the Flow Regulating Wetlands, at the influent to the Demonstration Wetlands, and from the Demonstration Wetlands if it discharges. (The discharge monitoring sampling work load is over four times what it was before the wetlands were added). Also, the EPA has required that a "Wetlands Assessment Study" be completed by August 2011 that will require extensive additional sampling within FRW1.

\subsection{Costs/benefits}

The City of Phoenix and the USACE have invested \$35 million to build the Tres Rios Wetlands and pumping station. Operating costs for the Flow Regulating Wetlands for the first year are estimated at about $\$ 1,500,000$. These costs, however, are extremely low compared to the construction and operating costs for tertiary filtration and advanced disinfection to a $230 \mathrm{mgd}$ facility. 
Arguably the greatest benefit is the additional 300 acres of wetland habitat, and the wildlife that is moving in. Since water was added to the FRW wetland cells numerous species of shore-birds, waterfowl, and raptors have frequented the site. There is a Great Blue Heron rookery adjacent to the site and they have been seen consuming fish from the wetlands. Most recently two American Bald Eagles have been frequenting the site. In addition to the avian visitors, mammals such as beaver, coyote, and bobcats have all been seen utilizing the newly created wetland habitat. The new "tenants" may ultimately include several endangered species endemic to the area including the Yuma Clapper Rail, the Southwestern Willow Flycatcher, the lesser long-nosed bat, and the Cactus Ferruginous Pygmy Owl, all on the federal endangered species list. The presence of these species may obligate the continued operation of the wetlands even if the economics and water allocations make it difficult. It is commendable that the USACE and City of Phoenix have embarked on this commitment to the environment.

\section{Conclusions}

The USACE and City of Phoenix have partnered to construct the Tres Rios Wetlands, and have provided the community with a resource with the potential for great benefit, as well as significant operational challenges and costs. Thus far, during this start-up period, the wetlands have become a home to large populations of birds, fish, and other animals. Operational costs and challenges have been essentially as predicted. Water "losses" due to evapotranspiration and infiltration have not exceeded predictions. Mosquito populations and invasive species, although present, have been under control. The cost of pumping and savings from reduced dechlorination chemical are as predicted. The regulatory agencies responsible for enforcing water quality regulations have been cooperative, while demanding careful monitoring.

A more complete analysis of the wetlands' capacity for water quality improvements will be available after the wetland vegetation and operating procedures have been fully developed in a few years. As more operational data is compiled, the value of the wetlands can be better assessed. Success is a wetlands that provides habitat, improves water quality, and reduces the costs associated with protecting the environment. It is hoped that this success prompts the execution of similar projects throughout the world.

\section{References}

[1] US Army Corps of Engineers, Tres Rios Arizona Feasibility Study Report, 2000.

[2] Williams, D, et al. Regulating and Overbank Wetlands, Design Documentation Report, RTA submittal. Prepared for City of Phoenix, April 2008

[3] City of Phoenix Internal Process Control Reports. 2010. 
[4] Wass Gerke \& Associates, Status Report to the 1998 Research Plan for the Tres Rios Demonstration Constructed Wetland Project. Prepared for US Bureau of Reclamation Phoenix Area Office, August 2001.

[5] Wass, R, et al. Tres Rios Water Quality Improvements, Ecosystem Restoration and Flood Damage Reduction in the Arid Southwest Desert. Proceedings of the Water Environment Federation, WEFTEC 2008: Session 51 through Session 60, pp. 4338-4356. 